УДК 342.9

DOI https://doi.org/10.32849/2663-5313/2020.2.35

Олександр Константий,

докт. юрид. наук, заслужений юрист Украӥни, науковий консультант суддi

Конституиійного Суду Украӥни

\title{
ДО ПИТАННЯ КОНСТИТУЦІОНАЛІЗАЦІЇ АДМІНІСТРАТИВНОГО ПРАВА І СУДОЧИНСТВА УКРАЇНИ
}

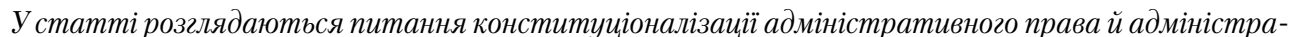
тивного судочинства України. Визнано неприйнятними підходи, що грунтуються на ідеї автономізації, структурного відокремлення адміністративного права від конституиійного права. Досліджено, що такі підходи мали місие у франиузькій та німецькій літературі у XIX - на початку XX століття. Нині такого роду догматика все ще переважає тільки в Австрії. Цим виправдовується існування незалежних одна від іншої систем конституиійної та адміністративної юстииї. В інших країнах Європи триває загальний тренд щодо глобалізачії правових систем. Тому зазначена точка зору про автономне існування адміністративного права не підтримується. Критерій джерела права не має ключового значення для структурування публічного права в сучасних європейських країнах.

Підкреслено, що в Україні поступово відбувається прощес конституиіоналізачї адміністративного права і практики адміністративного судочинства. Висловлено думку, що цей процес може пришвидиити закріплений у 2016 рочі в Конституції інститут конституиійної скарги. За чинним законодавством Конституиійний Суд України фактично повноважний перевіряти у процесі розгляду конституиійних скарг на предмет конституційності правозастосовну практику адміністративних судів. Механізм конституиійної скарги розглянуто практичним інструментом конституціоналізаціі як законотворення в адміністративно-правовій сфері, так і адміністративного судочинства в Україні, їх насичення ідеями утвердження та гарантування фундаментальних прав людини, закріпленими в Основному Законі України.

Під конституціоналізачією адміністративного права й адміністративного судочинства України запропоновано розуміти невпинний процес приведення системи начіональних адміністративно-правових норм, визначених у поточному адміністративному законодавстві, а також практики застосування иих норм суб'єктами публічного управління та адміністративними судами у відповідність до иіннісного змісту, ідей, закладених у приписах Конституції України та Конвенції про захист прав людини і основоположних свобод.

Ключові слова: Основний Закон, конституціоналізація, адміністративне право, судочинство, джерела права, основні права людини.

Постановка проблеми. Після здобуття Україною незалежності розпочався процес поступового оновлення на засадах народовладдя та верховенства права вітчизняного законодавства України, впровадження в його приписи загальноєвропейських підходів. Воно позбавлялося ідеологічних постулатів радянської доби, а основою для здійснення державою її функцій став невід'ємний для будь-якої демократії принцип поділу державної влади (на законодавчу, виконавчу і судову). 3 метою реалізації положень Основного Закону України були започатковані процеси формування законодавства про органи виконавчої влади різних рівнів, спеціалізованого адміністративного правосуддя для вирішення публічно-правових спорів, а також концептуальної трансформації вітчизняної адміністративно-правової теорії (на основі закріпленої в Конституції ліберально-правової доктрини) [1, с. 43, 85].

Однак останніми роками в українській адміністративно-правовій науці з'явилися невластиві їй до цього часу та 3 погляду сучасної доктрини права в країнах Свропи певною мірою забуті підходи, що грунтуються на ідеї «автономізації» адміністративного права (напевно, у зв'язку з тим, що воно стосується діяльності самостійної від законодавчої (політичної) влади системи органів виконавчої влади), його чіткого відмежування від конституційного права [2, с. 12]. Заперечення визнання Конституції України джерелом адміністративного права і водночас визначення цієї галузі права як «конкретизованого конституційного права» 
зумовлює виникнення в рамках «кардинальної реконструкції» вітчизняної його теорії цілого комплексу доктринально не вирішених проблем особливого, відмінного від сучасних європейських країн, шляху розвитку українського адміністративного права і судочинства.

Актуальність теми дослідження підтверджується незначною увагою вітчизняних науковців до розкриття проблем конституціоналізації адміністративного права і судочинства України, можливості їх глобалізації в рамках загального в Європі тренду уніфікації національних правових систем.

Стан дослідження. У сучасній українській юридичній науці питання конституціоналізації адміністративного права і судочинства майже не розроблені. Окремі аспекти проблеми висвітлювали у своїх публікаціях Ю. В. Ващенко, Т. О. Коломоєць, Л. І. Летнянчин, Р. С. Мельник, Т. С. Подорожна та деякі інші науковці.

Метою статті $\epsilon$ пошук теоретичних підстав для розвитку і вдосконалення наукових знань та чинної системи адміністративноправового регулювання і конституціоналізації правозастосування в Україні.

Виклад основного матеріалу. Запропонований для української адміністративноправової науки підхід, що грунтується на ідеї суворого відокремлення адміністративного права від конституційного, дискутувався науковцями в Свропі ще у XIX - перші десятиліття XX століття. Нині він переважає як свого роду данина традиції тільки в юридичній науці в Австрії. Зокрема, у цій країні 3 масиву адміністративного права виключаються усі норми конституційного рангу та дотепер догмою $є$ запропонована ще у 1927 році Адольфом Мерклем [Adolf Merk] (1890-1970)] у праці «Загальне адміністративне право» (Allgemeines Verwaltungsrecht) $[3$, c. 79,85$]$ формула, за якою існує сувора відокремленість як ієрархічно, так і змістовно конституційного права та адміністративного. Застосування зазначеної формули, на думку австрійських науковців, виправдовуе допустимість такого, що склалося історично, «паралельного» функціонування відокремлених одна від іншої систем конституційної та адміністративної судових юрисдикцій $[4$, с. 3, 4, 6]. Подання конституційної скарги в цій країні не пов'язується з вичерпанням засобів правового захисту у звичайних (адміністративних) судах.

Однак австрійський підхід на теренах Європи нині є рідкісним. Триває загальний тренд щодо глобалізації правових систем (у тому числі адміністративного права) усіх країн-членів ЄС. Відбується наповнення їх адміністративно- і приватно-правових норм «духом» не тільки конституцій (внаслідок значної ролі рішень конституційних судів), а і прецедентів 3 тлумачення Хартії основних прав людини СС та Конвенції про захист прав людини і основоположних свобод (далі - Конвенція) згідно із Судом ЄC та Європейським судом з прав людини (далі - ССПЛ) [5, с. 139]. Критерій джерела права (чи є воно Конституцією чи звичайним законом) нині не має домінуючого значення для вирішення питань структуризації норм публічного права в європейських державах (крім Австрії). Немає і жорсткого ранжування правових підстав для вирішення спорів звичайними судами, оскільки рішення адміністративних судів також, як правило, перебувають в системі «контролю» (підлягають оцінці на предмет дотримання основних прав людини, гарантованих конституціями) конституційного судочинства (Іспанія, Словенія, Словаччина, Україна, ФРН, Чехія, Чорногорія тощо). Практика конституційних судів, маючи преюдиційний характер, нині у більшості країн Свропи конституціоналізує, безпосередньо визначає зміст i характер поточного законотворення і правозастосування звичайних судів.

Однак «конституціоналізація» нині становить ідею розвитку не тільки «внутрішньодержавного» права європейських країн, a i наднаціонального acquis communautaire. Під цим поняттям Ларрі Ката Бекер розуміє процес втілення ідей Конституції, конституційних цінностей у правову систему держави, «теоретизації» іiї правового простору [6]. На думку А. Петерса, «конституціоналізацією» є: по-перше, формування конституційного права в рамках правового порядку i, по-друге, поширення конституціоналізму як інтелектуальної течії у праві загалом [7, с. 250]. Т. С. Подорожня своєю чергою визначає конституціоналізацію основним аспектом розвитку правової системи України, одним із виявів безпосередньої дії конституції, спрямованим на гармонізацію суспільних відносин і реалізацію принципу верховенства права [8, с. 180-188].

Перенесення в українську науку тих, що існували у німецьких та французьких виданнях на початку минулого століття, теоретичних дискусій щодо чітких меж і особливих джерел конституційного та адміністративного права [9, с. 59-73] поставило перед представниками вітчизняного «адміністративно-правового світу» як необхідний предмет доктринального вирішення такі проблемні питання: 1) якщо Конституція України розглядається джерелом виключно 
конституційного права, то тоді джерелом якої галузі права має розглядатися Конвенція, в якій закріплено приблизно такий же перелік фундаментальних прав людини, як і в розділі ІІ національного Основного Закону; 2) чи можна у рамках структурного підходу розглядати як джерело адміністративного права та судочинства Конвенцію, адже власне адміністративно-правових і адміністративно-судочинських норм вона не містить; 3) чи відповідають підходи, що передбачають «джерельну автономію» адміністративного права, загальній сучасній європейській тенденції щодо глобалізації цієї галузі права? [10, с. 38, 39].

Відповіді на ці питання криються, напевно, у пошуку загалом мети поділу права на галузі, а також меж і потреби застосування для дослідження та описання правових явищ переважно системно-структурного, а не інших, у тому числі діалектичного, підходів. Адже відомо, що галузевий поділ права спочатку був спрямований на послідовну та змістовну класифікацію законодавства, навчального та наукового матеріалу, тобто він проводився з прикладних позицій [11, с. 309], насамперед для потреб більш зручного вивчення права. Суворе застосування цього методу не призвело до того, що норми усіх, а не тільки одиничних, галузей права нині кодифіковані в одному акті законодавства. Слідування методології суто системно-структурного підходу само по собі не вирішує проблеми кодифікації (упорядкування) «адміністративно-правового світу» та змістовно-якісного оновлення його теорії за обставин проголошеної іï реконструкції.

У сучасних конституційних державах Європи теза про два окремих «світи» конституційного та адміністративного права $є$ немислимою. Застосування історико-правового методу дозволяє з'ясувати, що теза про окреме існування цих двох галузей права була наведена у 1924 році (у період важкого становлення Веймарської Республіки після падіння імперії) відомим німецьким адміністративістом Отто Майєром [Otto Mayer $(1846-1924)]$. Безумовно, не можна стверджувати, що наявні в сучасній українській літературі новітні підходи до структурування норм та джерел адміністративного права як частини публічного права [12, с. 116] прямо зумовлені саме намаганнями авторів провести певні паралелі між нестійкими з позицій утвердження конституціоналізму Україною та постімперською Вермаймарською Республікою. Але позиції, які висловлюються останніми роками у публікаціях 3 адміністративноправової тематики в нашій державі, наштов- хують на думку про імпліцитну підтримку їх авторами ідей Отто Майєра.

Так, у передмові до третього видання свого підручника «Німецьке адміністративне право» (Deutsches Verwaltungsrecht) (1924 р.) Отто Майєр заявив, що «конституційне право минає, адміністративне право залишається» (Verfassungsrecht vergeht, Verwaltungsrecht besteht) [13, с. 46]. При цьому науковець цитував французького професора адміністративного права Теофіла Дюрокка (1829 - 1913), який в контексті бурхливої конституційної історії Франції також стверджував, що існує все ж таки «певна стабільність адміністративного права» [4, с. 12].

Отто Майєр грунтував свою позицію на існуванні обставин більш тривалого за конституційні зміни процесу оновлення адміністративного права, відмічаючи, що якщо конституцію (ії̈ окремі норми) можна змінити досить швидко (потрібно оновити тільки відповідний текст), то для впровадження конституційних принципів у масив адміністративного законодавства та судової практики потрібно значно більше часу. Отже, вказана вище заява була зроблена Отто Майєром 3 огляду на «стійкість до змін» адміністративного права. Зазначена проблема особливо гостро постала у Німеччині після Другої світової війни, коли реалізація нових конституційних демократичних принципів, закріплених в Основному Законі 1949 року (Grundgesetz), була досить повільною. Адміністративне право ФРН ще певний період часу містило приписи, запроваджені за фашистських часів.

Однак нині тісна взаємозумовленість конституційного та адміністративного права визнається у більшості європейських країн. Їхні правові системи водночас зазнають уніфікації та наповнення природно-правовим змістом прав людини (під впливом практики страсбурзької конвенційної системи та дії Хартії основних прав як частини «конституції» Європейського Союзу). У ФРН особливо (після жахів нацистської диктатури) простежується тенденція до максимального розширення впливу Конституції (закріплених у ній прав людини) на розвиток адміністративного права та практики адміністративних судів. Засобом цього виступає й інструментарій подання до Федерального конституційного суду цієї країни конституційної скарги не тільки проти закону, а й проти акта, дії чи бездіяльності установи або органу влади (протягом одного місяця після вичерпання усіх засобів правового оскарження (п. 8a § 13, §92 Закону про Федеральний конституційний суд (BverfGG)) 
[14]. У зв'язку з цим Федеральний конституційний суд у ФРН вважається центральним суб'єктом, який керує процесом конституціоналізації (наповнення змістом, ідеями Конституції) правової системи.

Армін фон Богданді та Петер М. Хубер відзначають, що Основним Законом ФРН вердикт Отто Майєра про конституційний нейтралітет адміністративного права був відхилений. Вперше в німецькій конституційній історії, визначивши пряму пов'язаність всіх гілок влади основними правами (абз. 3 ст. 1 Основного Закону ФРН), конституція позбавила законодавство автономії, включаючи адміністративне право, і разом з тим заклала фундамент для його конституціоналізації, що досягла свого апогею на початку 1990-х років. Тому процес розвитку сучасного німецького адміністративного права називають ще історією його «пов'язування основними правами» («Vergrundrechtlichung») [15, c. 43].

Отже, у ФРН під впливом абз. 3 ст. 1 Основного Закону утвердилася точка зору, що основні права повинні діяти також у правовідносинах, які раніше позначалися як «особливі владні» (адміністративно-правові відносини) [15, с. 46]. 31949 року яскраво простежується шлях еволюції німецького адміністративного права, що, зокрема, передбачає його конституціоналізацію. Адміністративно-правова галузь з погляду позитивістики вже більше не мислиться без її конституційного фундаменту, орієнтації і тісного взаємозв'язку 3 конституційним правом. Зазначене має наслідком те, що в контексті правової практики розрізнення адміністративного права та конституційного права визнається проблематичним. «Вирівнювання» обох царин публічного права призвело до того, що відсутні відмінності і в плані теорії джерел цих галузей права $[15$, с. 66$]$.

Незважаючи на значні труднощі ментального та законотворчого плану, в Україні поступово все таки відбувається процес конституціоналізації адміністративного права і практики адміністративного судочинства. $€$ сподівання, що у майбутньому фундамент для цього процесу становитиме закріплений в 2016 році в Конституції інститут конституційної скарги. Відповідно до Закону України «Про Конституційний Суд України» від 13 липня 2017 року № 2136-VIII (статті 55 77) кожній фізичній та юридичній особі приватного права після вичерпання засобів правового захисту її прав, у тому числі порушених у відносинах з публічною адміністрацією, в судах загальної юрисдикції (тобто і в адміністративних судах апеля- ційної інстанції чи касаційної інстанції) надано право звернутися 3 конституційною скаргою (письмовим клопотанням) до Конституційного Суду для проведення перевірки на предмет відповідності Конституції України (конституційності) закону України (його окремих положень), що застосований в остаточному судовому рішенні в її справі. Отже, нині в Україні, як і у ФРН та інших державах Свропи, рішення адміністративних судів фактично підлягають оцінці (перевірці) на предмет дотримання під час їх ухвалення норм Конституції, основоположних прав людини у провадженні в Конституційному Суді. Визнання органом конституційної юрисдикції неконституційною норми закону, яка застосовувалася адміністративними судами під час вирішення публічно-правового спору, $є$ підставою для перегляду відповідно постанов апеляційного або Касаційного адміністративного суду чи Великої Палати Верховного Суду за виключними обставинами (пункт 1 частини п'ятої статті 361 Кодексу адміністративного судочинства України (далі - КАС України)).

Водночас новелою $є$ те, що якщо за результатами розгляду справи за конституційною скаргою Конституційний Суд України визнає закон України (його положення) таким, що відповідає Конституції України, але одночасно виявляє, що суд загальної юрисдикції застосував закон України (його положення), витлумачивши його у спосіб, що не відповідає Основному Закону, то орган конституційної юрисдикції вправі вказати на це у резолютивній частині рішення (частина третя статті 89 Закону «Про Конституційний Суд України»). Такий механізм виступає, на наш погляд, практичним інструментарієм конституціоналізації не лише законотворення в адміністративно-правовій сфері, а й адміністративного судочинства, розвитку його у загальноєвропейському руслі насичення ідеями утвердження та гарантування фундаментальних прав людини.

Поряд із наведеним вище, не можна не відзначити кардинальної зміни моделі (способу) застосування адміністративними судами України під час вирішення публічно-правових спорів норм законодавства, щодо яких існують сумніви в їх конституційності, у редакції КАС України від 3 жовтня 2017 року. Так, у частині четвертій статті 7 чинної редакції цього Кодексу закріплено, що, якщо суд доходить висновку, що закон чи інший правовий акт суперечить Конституції України, суд не застосовує такий закон чи інший правовий акт, а застосовує норми Конституції України як 
норми прямої дії. У такому випадку адміністративний суд тепер тільки після винесення рішення у справі, а не до цього (як було раніше) звертається до Верховного Суду для вирішення питання стосовно внесення до Конституційного Суду України подання щодо конституційності закону чи іншого правового акта парламенту, глави держави чи уряду. Таке закріплене у КАС України правило робить адміністративні суди України безпосереднім суб'єктом «охорони Конституції», є одним зі способів конституціоналізації норм публічного (у тому числі адміністративного) права.

\section{Висновки}

Під «конституціоналізацією адміністративного права і судочинства України» вважаємо допустимим розуміти невпинний процес приведення системи національних адміністративно-правових норм, визначених у поточному адміністративному законодавстві, та практики їх застосування (як суб'єктами публічного управління, так i адміністративними судами) у відповідність до ціннісного змісту, ліберальних ідей, закладених у приписах Конституції України, a також міжнародно-правових договорів, насамперед Конвенції, які отримують інтерпретації, роз'яснення, відповідно, у практиці (рішеннях) Конституційного Суду України та Свропейського суду з прав людини.

У складному процесі утвердження правової держави в Україні на фоні неквапливих кроків законодавця у справі оновлення на основі приписів Конституції України адміністративного законодавства (за умов все ще дії КУпАП 1984 року, неприйняття закону «Про адміністративну процедуру» тощо) помітну роль в конституціоналізації адміністративно-правової сфери можуть відгравати адміністративні суди, які за чинними положеннями КАС України наділені компетенцією безпосередньо застосовувати норми Основного Закону як норми прямої дії, керуватися практикою ССПЛ та визнавати неконституційними (нечинними) нормативно-правові акти міністерств, інших центральних та місцевих органів виконавчої влади, органів місцевого самоврядування.

\section{Список використаних джерел:}

1. Адміністративне право України. Академічний курс : підручник : у 2-х т. Том 1. Загальна час- тина / ред. колегія: В. Б. Авер'янов (голова). Київ : «Юридична думка», 2004. 584 с.

2. Мельник Р.С. Новели сучасної концепції українського адміністративного права. Lex portus. 2017. № 5 .

3. Adolf Merkl. Allgemeines Verwaltungsrecht. Verlag Österreich, 1999. 400 p.

4. Heuschling Luc. The Complex Relationship between Administrative Law and Constitutional Law. A Comparative and Historical Analysis. The Max Planck Handbooks in European Public Law. Vol. 1. The Administrative State. § 14. URL: http://hdl.handle.net/10993/17920 (дата звернення: 01.12.2019).

5. Мартинес А.К. Адаптация административного права в современном государстве. Вестник Университета им. О.Е. Кутафина. 2015. № 5.

6. Larry Catá Backer. The Concept of Constitutionalization and the Multi-Corporate Enterprise in the 21st Century. URL: https://papers.ssrn.com/ sol3/papers.cfm?abstract_id=2458965 (дата звернення: 21.12.2019).

7. Петерс А. Правовые системы и процесс конституционализации: новое определение соотношения. Дайджест публичного права Института Макса Планка. Выпуск 2 (2013). URL: http://dpp.mpil.de/02_2013/art2_6.cfm. (дата звернення: 21.12.2019).

8. Подорожна Т. С. Конституціоналізація правового порядку через призму верховенства Конституції. Право України. 2014. № 3.

9. Maurice Hauriou. Précis de droit administratif, contenant le droit public et le droit administratif. 2e édition (Français). Hachette Livre BNF, 2017. $800 \mathrm{p}$

10. Винце Аттила. Европеизация национального административного права - сравнительноправовое исследование. URL: https://dpp.mpil.de/ 07_2018/07_2018_37_77.pdf. (дата звернення: 11.12.2019)

11. Хряпченко В.П. Від критеріїв поділу системи права на галузі до комплексних галузей права. Актуальні проблеми політики. 2015. Вип. 55.

12. Мельник Р.С. Загальне адміністративне право в питаннях і відповідях. Киъв : Юрінком Інтер, 2019. $308 \mathrm{c}$.

13. Otto Mayer. Deutsches Verwaltungsrecht. 3. Aufl. München, 1924.791 p.

14. Bundesverfassungsgerichtsgesetz, BVerfGG. URL: https://www.gesetze-im-internet.de/bverfgg/ index.html \#BJNR002430951BJNE011702305 (дата звернення: 11.12.2019).

15. Армин фон Богданди, Петер М. Хубер Государство, государственное управление и административное право в Германии. URL: https://dpp.mpil.de/03_2014/03_2014_1_68.pdf. (дата звернення: 11.12.2019). 
The article deals with the constitutionalization of the administrative law and the administrative court process of Ukraine. Approaches based on the idea of autonomy, the structural separation of administrative law from constitutional law, have been declared unacceptable. It has been investigated that such approaches took place in French and German literature in the 19th and early 20th centuries. Nowadays, this kind of dogma is still prevalent only in Austria. This justifies the existence of independent systems of constitutional and administrative justice. In other European countries, there is a general tendency to globalize legal systems. Therefore, this view of the autonomous existence of administrative law is not supported. The criterion of the source of law is not crucial to the structuring of public law in modern European countries.

It is emphasized that in Ukraine there is a gradual process of constitutionalization of administrative law and practice of administrative justice. It is suggested that this process will speed up the institute of constitutional complaint enshrined in the Constitution in 2016. The mechanism of the constitutional complaint was considered as a practical instrument of constitutionalization of both law-making in the administrative and legal sphere in Ukraine, their saturation with ideas of asserting and guaranteeing fundamental human rights.

Under the constitutionalization of administrative law and administrative justice of Ukraine it is offered to understand the continuous process of bringing the system of national administrative-legal norms defined in the current administrative legislation, as well as the practice of applying these norms by the of public administration and administrative courts in accordance with the valuable content, ideas, provisions of the Constitution of Ukraine and the Convention for the Protection of Human Rights and Fundamental Freedoms.

Key words: Basic Law, constitutionalization, administrative law, administrative justice, sources of law, basic human rights. 